\title{
In Memoriam. Dan Callahan: Writing a Life in Bioethics
}

\author{
JOSEPH J. FINS
}

Daniel Callahan died on July 16, 2019, days before his $89^{\text {th }}$ birthday. A pioneering intellect who eschewed the confines of the academy to co-found the Hastings Center and launch a field, Dan was a crisp thinker, a certain writer, and a devout communitarian. And he was a fantastic mentor who shaped bioethics through his personal imprint on the many scholars who he trained and influenced. I am personally in his debt and while I mourn this loss, I am immensely grateful that Dan lived a full life pursuing ideas with passion and intelligence until his final days. Just weeks before he died he chaired a meeting at the Hastings Center on the ethics of climate change. Colleagues who were there say he was in fine form.

Climate change. It was the latest issue to trigger Dan's capacious curiosity. ${ }^{1}$ For decades he anticipated trends, first as a preeminent lay Catholic intellectual after Vatican II and editor of Commonweal, ${ }^{2}$ then as a bioethicist. It would not be hyperbole to assert that Setting Limits ${ }^{3}$ anticipated and catalyzed health care reform, and that The Troubled Dream of Life: Living with Mortality ${ }^{4}$ was instrumental in prompting a national discussion about palliative care and how we die. Dan was always looking forward, and yet, his passing prompts us to look back. It is indisputable that his death represents a generational shift for bioethics, with the loss of one of its remaining founders.
Others like Amy Gutmann, ${ }^{5}$ president of the University of Pennsylvania, and Tom Murray ${ }^{6}$ and Millie Solomon,7 two who followed him as presidents of the Hastings Center, have written beautiful tributes. Millie's essay, in particular, is a true accounting of the depth and scope of Dan's work, an intellectual history which I will not repeat here. Instead, my goal is to share some personal memories of Dan to highlight his devotion to three things he cherished: community, mentoring, and writing. These three elements often coalesced with enduring benefit for aspiring bioethicists whose lives he touched, mine included.

It is impossible to separate the Center from Dan, or Dan from the Center. He crafted it in his own image, informed by values of the good life, not coincidentally the theme of a memoir published in 2012. ${ }^{8}$ For Dan, the good life was centered on community, and the Center was a community of interdisciplinary scholars each committed to the pursuit of knowledge to improve the commonweal using methods from their particular discipline. But that was not enough. Everyone had to be cross-trained and conversant with the methods of others to create synergies. The Center was interdisciplinary long before interdisciplinarity came into vogue.

This was the case from the start, and epitomized by Dan's partnership with

Acknowledgements: This essay is dedicated to the memory of Dan Callahan. 
physician and psychoanalyst, Will Gaylin, his Hastings-on-Hudson neighbor with whom he co-founded the Center in 1969. Together, they recognized that no single discipline had hegemony over the complex questions that they hoped to address. To work and thrive at the Center, one had to transcend one's academic parochialism and cross the proverbial two-culture divide. And when one disagreed with a colleague, civility would reign. Arguments would be respectful and collegial, rigorous and logical. There was no place for ad hominem arguments or ideologues.

Within these constraints, Dan was never shy to disagree. In fact, at one anniversary celebration, Dan proposed a medieval disputation as a way to celebrate his work. Hastings Center associates were each tasked to moderate a panel of leading scholars who would take on one of Dan's books or arguments. Then Dan would get to reply. There were several panels: This was Dan's idea of fun.

Even Dan and Will disagreed. At Dan's wake, Will told me that when they didn't agree, it was always a friendly disagreement. In fact, Will recalled that when Dan told him he wanted to start an institute-the original name for the Center was the Institute of Society, Ethics and the Life Sciences-Will said, "You can't start an institute." Later, he told me he knew that eventually everyone would just call it The Hastings Center. Dan got his institute and Will the naming rights. Theirs was a beautiful collaboration that spanned five decades.

I first met Dan in 1989 when I was a Visiting Scholar at The Hastings Center, during the final year of my residency in internal medicine. ${ }^{9}$ It was an unusual use of elective time but I appealed to my chairman to let me go. I asked him to consider it akin to the lab electives many of my resident-mates took at The Rockefeller University to explore their interests in research. This would be my "lab time" to explore bioethics. Fortunately, my chair bought my argument and even more fortuitously the Center family welcomed me into their fold.

Consistent with Dan's vision-and mandate-each day, we would all gather together to break bread around a large table in the library. We were summoned by a bell that was rung precisely at 12:30. If you were in the building and not on the road giving a talk, you had to attend. As I recall, lunch was four dollars and basically left-overs supplied by a local high-end caterer. While the food was good and cheap, the conversation was what really sparkled.

At each meal, one of us would be tasked to give a brief talk about our work, followed by a robust discussion. Visitors would present their ideas on arrival, and be introduced to the Hastings Center associates. At the conclusion of their visit, each would share the results of their studies and future plans. For the Visiting Scholars, these lunches were formative. Many of us were young and intimidated by the Center's history and reputation, but these required talks gave us the chance to present and learn.

Along the way, the associates-the Center's professional staff-would talk about their new projects or a breaking news item. I vividly remember when Susan Wolf, then the Associate for Law and now a professor at the University of Minnesota, walked us through the Supreme Court decision in Cruzan. She read the opinion off glossy paper fresh from a fax machine. Despite the primitive technology, what could be better than to learn and grow together and benefit from expert analysis from folks like Susan, or to hear from emerging scholars from around the world? Not 
infrequently, what happened informally at lunch led to academic collaborations and life-long friendships. The impact on bioethics was almost imperceptible in the moment but each time a connection was made, Dan's vision for community was affirmed.

As a resident physician, going up to the Center was an incredible experience. The intellectual richness is hard to describe and was almost overwhelming. Each night, as I drove back to the City, my head flooded with new ideas to consider and write about. At that time, Dan was really into the ethics of priority-setting, and at a microlevel, I had to decide what areas of inquiry I would prioritize.

But first, I had to figure out how to do bioethics as a career. It was an unchartered path at that time and I needed guidance. And then one afternoon, toward the end of my stay, Dan surprised me when he came down to the basement of the Center, then in its second home in Briarcliff Manor. I was in a dimly lit orange and white cubicle reading, and there was Dan waiting to talk to me. It was surreal because no one on staff, much less Dan Callahan, came down to the basement. And then the most incredible thing happened: he offered me a job as a Visiting Associate!

Needless to say, this was a life-altering moment, and I would not have had the life I have had, were it not for Dan's visit to the basement and his generous offer. Although I had already accepted a fellowship in general internal medicine for the next two years I was able to incorporate a few days a week at the Center when I was not on call. When I was done with my fellowship, I was able to stay on as the Associate for Medicine, as I started my academic career at Cornell's medical school.

Like everyone who worked at the Center, I benefitted from Dan's example, habits of mind, and mentoring.
To watch him turn an idea into a grant proposal or to populate a Hastings Center meeting with world experts was to watch a masterpiece in the making. It was a rarefied educational opportunity to learn by doing. Each meeting was another component of my education. For a novice bioethicist, each project was like a semester of graduate school given all the preparatory work, the meetings, and the drafting of final reports.

Even still, I did ask Dan about going to graduate school to supplement my humble training as a physician. If I aspired to be a meta-physician, didn't I need to pursue a Ph.D. in the humanities? While I had done intellectual history as an undergraduate at Wesleyan, was that enough? Dan had a simple and dismissive answer. To paraphrase his advice, you don't need to go to graduate school. Every ten papers is a Ph.D. Just better to write, and then write more. That was how one truly learned and gained mastery over a topic.

Writing was the key to understanding Dan. It was his anchor, his way to express himself. Although he was great at argumentation, he seemed more the introvert than extrovert. The true force of his mind was expressed in writing. It was a passion of his that he enjoyed and did exceedingly well with precision and dispatch. He was also a superb editor, birthing The Hastings Center Report, which he may have loved even more than the Center itself.

The true miracle, though, was that he managed to write so well and prolifically given his "day job" as president of the Center (and father of six!). So when people said they had no time to write he had little time for excuses. To drill home the point, he wrote a gem of a memo that he circulated to the associates entitled, How to Get Your Writing Done When (You Think) You Have No 
Time To Write. The caps and bold font are in the original as if for emphasis. It is a brilliant memo. Typically Dan, laconic with a clear purpose.

After Dan's death, I shared a copy with David Roscoe, a past chair of the Hastings Board who thanked me for "this treasure," adding "it is so Dan. I betcha he wrote it in one day, no more than two drafts, walking the talk...such a great role model." So true.

But if he wanted us to be prolific writers and meet the implicit expectation at the Center that we should publish ten articles a year, we needed both his example and his guidance. And he provided both. We reasoned that if Dan could publish a book every year or two, while dashing off essays, we could publish at a fraction of that clip, empowered by his good advice.

The memo starts off by explaining that his guide was not on how to write well but on how to get the work done. He explains:

These rules have nothing to do
with good writing. They are about
getting the writing done. Their
aim is to help one understand that
writing is a discipline, best done
in an orderly and persistent, even
dogged, way. They are particu-
larly pertinent to those who
believe they have little or no time
to write, overwhelmed by other
duties. I hold the following to be a
true axiom: if you have something
to say, you will find time to write.
It is there between the cracks of
your life. ${ }^{10}$

There are a total of 10 rules. They start with having something to say, writing from an outline, meeting or beating editors' deadlines, adhering to word limits, avoiding jargon and using lively and accessible prose. He advised us to "eschew perfectionism," and to use emails and memos to practice our craft.
To Dan, writing was like exercise: if you did it all the time, it became easier. And then, there was advice about time management, urging us "to set apart time away from work to write where there are no distractions." He concluded by advising us to make our own rules.

This little memo, just over two pages, has been the key to any success I might have had as a writer. It has helped me stay disciplined, focused, and productive. Indeed, in the spirit of Dan's last admonition, I have added my own rules and now routinely give a talk to my trainees based on Dan's original ten. It is a gift that keeps on giving. In the spirit of generational fluxes, Dan's advice is now reaching people who will never know him.

On a more sobering note, Dan also modeled fairness as a leader. Early during my time as an associate, the Center ran into one of its perennial shortfalls of cash. Austerity had set in, and Dan called me in to let me go. It wasn't personal or a reflection on the quality of my work. Instead, it was about need. I was a physician and a part timer at the Center which was paying only a fraction of my salary. I was dependent upon my medical school for the rest. If I lost the position at the Center I would be fine, at least economically. Not so for other associates who were totally dependent upon the Center for their income.

With the veil of ignorance unblinded, it was the only decision he could possibly make. I was devastated because I desperately did not want to have to leave the Center. It had become home. Fortunately, Dan and Will approached a Center philanthropist, the late Beatrice Greenbaum, who made a gift that allowed me to stay. I remain grateful to Bea, and to Dan and Will, for taking account of both the utilitarian and deontological dimensions of organizational austerity. My relationship with 
the Center continued and I remain connected as a Fellow and current board member.

Years ago, Dan wrote a book called What Kind of Life: The Limits of Medical Progress. ${ }^{11}$ His was the kind of life to which all public intellectuals aspire: One of meaning, commitment, and impact. Dan's legacy will live on in both his scholarly achievements and the field he helped mold, both as an institution builder and a dedicated mentor. He will be missed, but remembered as long as we contemplate bioethical issues. Let's take a moment to pause and be grateful for having people like Dan Callahan in our lives.

\section{Notes}

1. Callahan D. The Five Horsemen of The Modern World: Climate, Food, Water, Chronic Illness, and Obesity. New York: Columbia University Press; 2016.

2. Lauritzen P. Daniel Callahan \& Bioethics; Where the best arguments take him. Commonweal May 28, 2007; available at https: / / www.commonwealmagazine.org/ daniel-callahan-bioethics (last accessed 22 July 2019).
3. Callahan D. Setting Limits: Medical Goals in an Aging Society. New York: Touchstone Books; 1988.

4. Callahan D. The Troubled Dream of Life: Living with Mortality. New York: Simon \& Schuster; 1993.

5. Gutmann A. Daniel Callahan - A remembrance. The Hastings Center Bioethics Forum. July 19, 2019; available at https://www. thehastingscenter.org/publications-resources / forum/ (last accessed on 22 July 2019).

6. Murray T. A tribute to Daniel Callahan 1930-2919. Bioethics.net July 18, 2019; available at http://www.bioethics.net/2019/07/ a-tribute-to-daniel-callahan-1930-2019/ (last accessed 22 July 2019).

7. Solomon MZ. Daniel Callahan: In memoriam. The Hastings Center Bioethics Forum. July 18, 2019; available at https://www. thehastingscenter.org/daniel-callahan-inmemoriam/ (last accessed 22 July 2019).

8. Callahan D. In Search of the Good: A Life in Bioethics. Cambridge, MA: The MIT Press; 2012.

9. Fins JJ. My time in medicine. Perspectives in Biology and Medicine 2017;60(1)19-32.

10. Callahan D. How to Get Your Writing Done When (You Think) You Have No Time To Write. Manuscript in possession of the author. Date, unknown.

11. Callahan D. What Kind of Life: The Limits of Medical Progress. New York: Simon \& Schuster; 1990. 